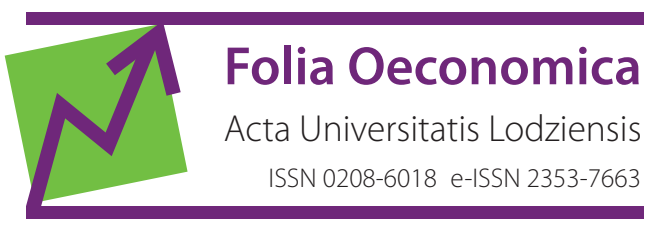

www.czasopisma.uni.lodz.pl/foe/

3(342) 2019

DOI: http://dx.doi.org/10.18778/0208-6018.342.03

\title{
Maria Trojanek
}

Wyższa Szkoła Bankowa w Poznaniu, Instytut Finansów i Bankowości

maria.trojanek@wsb.poznan.pl

\section{Strategiczny wymiar gospodarowania komunalnym zasobem nieruchomości}

Streszczenie: Celem artykułu jest wskazanie zasadności strategicznego podejścia do gospodarowania nieruchomościami komunalnymi. W rozważaniach przedstawiono prawne i ekonomiczne aspekty gospodarowania, a także wskazano na specyfikę i cele gospodarowania nieruchomościami komunalnymi. Zidentyfikowano argumenty uzasadniające zmianę modelu gospodarowania nieruchomościami komunalnymi, wskazując, iż podstawą procesu gospodarowania zasobem nieruchomości komunalnych powinna być klasyfikacja nieruchomości ze względu na realizację (obecnie i w przyszłości) zadań gminy i potrzeby wynikające z dokumentów strategicznych. W rozważaniach przedstawiono ponadto działania podejmowane w kolejnych etapach opracowywania strategii gospodarowania zasobem komunalnym.

Słowa kluczowe: gospodarowanie nieruchomościami, cele gospodarowania nieruchomościami, strategia gospodarowania nieruchomościami

JEL: R5, H7, K3 


\section{Wprowadzenie}

Zmiany w gospodarowaniu nieruchomościami w sektorze publicznym w krajach o gospodarce rynkowej, w których rozwój rynku nieruchomości dokonywał się na drodze ewolucyjnych przemian, miały miejsce na przełomie lat siedemdziesiątych i osiemdziesiątych ubiegłego wieku. Wynikały one z potrzeby:

1) racjonalizacji kosztów utrzymania zasobu,

2) profesjonalizacji zarządzania nieruchomościami,

3) rozdzielenia odpowiedzialności użytkownika i właściciela,

4) zwiększenia efektywności gospodarowania tym zasobem.

Podobne zjawiska, choć o różnorodnej skali i zakresie, występują w krajach, w których dokonują się zmiany systemowe, w tym w Polsce. W krajach, w których reaktywowano samorząd terytorialny, zmiany te zdeterminowane są dodatkowo (Kaganova, Nayyar-Stone, 2000):

1) odejściem od dominującej roli i znaczenia własności państwowej w gospodarce,

2) coraz częstszym postrzeganiem nieruchomości publicznych jako aktywów generujących korzyści finansowe,

3) wdrażaniem zasad rynkowych do gospodarki nieruchomościami,

4) zmianą pozycji podmiotu publicznego $z$ dostarczyciela usług i dóbr publicznych na partnera i regulatora relacji podmiot publiczny-użytkownik.

W artykule przedstawiono specyfikę gospodarowania nieruchomościami w gminach oraz wskazano na konieczność strategicznego podejścia w gospodarowaniu tym zasobem.

\section{Prawne i ekonomiczne aspekty gospodarowania nieruchomościami}

W Ustawie z dnia 21 sierpnia 1997 r. o gospodarce nieruchomościami (UoGN) nie zdefiniowano pojęcia gospodarowania, wymienione zostały jedynie czynności podejmowane w ramach gospodarowania zasobem nieruchomości w kolejności: Skarbu Państwa, gminnym, powiatowym i wojewódzkim (art. 23, 25, 25b i 25d). Przepisy cytowanej ustawy nie mają zastosowania do gruntów przeznaczonych na cele rolne i leśne, jak również do nieruchomości przeznaczonych na cele szczególne oraz nieruchomości lokalowych. Problematyka gospodarowania tymi nieruchomościami została uregulowana w odrębnych ustawach, a wykaz tych ustaw zawiera artykuł 2 UoGN.

Z treści zapisów UoGN wynika, iż gospodarowanie nieruchomościami Skarbu Państwa (art. 23.1) obejmuje procedury prawne i czynności faktyczne, a w szczególności: 
1) ewidencjonowanie nieruchomości zgodnie $z$ katastrem nieruchomości (ewidencja gruntów i budynków);

2) zapewnienie wyceny nieruchomości z zasobów;

3) sporządzanie planów wykorzystania zasobów;

4) zabezpieczenie nieruchomości przed uszkodzeniami lub zniszczeniami;

5) wykonywanie czynności związanych $\mathrm{z}$ naliczaniem należności za nieruchomości udostępniane z zasobów oraz prowadzenie windykacji tych należności;

6) współpracę z innymi organami, które gospodarują na mocy odrębnych przepisów nieruchomościami Skarbu Państwa, a także z właściwymi jednostkami samorządu terytorialnego;

7) zbywanie oraz nabywanie nieruchomości tworzących zasób za zgodą odpowiednio: wojewody, rady gminy, rady powiatu, sejmiku województwa;

8) wydzierżawianie, wynajmowanie i użyczanie nieruchomości wchodzących w skład zasobu; w przypadku gdy umowa zawierana jest na czas oznaczony dłuższy niż trzy lata lub czas nieoznaczony, wymagana jest zgoda wojewody; zgoda wojewody jest wymagana także w przypadku, gdy po umowie zawartej na czas oznaczony do trzech lat strony zawierają kolejne umowy, których przedmiotem jest ta sama nieruchomość;

9) podejmowanie czynności w postępowaniu sądowym, w szczególności w sprawach dotyczących własności lub innych praw rzeczowych na nieruchomości, o zapłatę należności za korzystanie z nieruchomości, o roszczenie ze stosunku najmu, dzierżawy lub użyczenia, o stwierdzenie nabycia spadku, o stwierdzenie nabycia własności nieruchomości przez zasiedzenie;

10) składanie wniosków o założenie księgi wieczystej dla nieruchomości Skarbu Państwa, jednostek samorządu terytorialnego oraz o wpis w księdze wieczystej.

Gospodarowanie gminnym zasobem nieruchomości polega w szczególności (art. 25 ust. 2) na wykonywaniu czynności wyżej wymienionych oraz na:

1) przygotowywaniu opracowań geodezyjno-prawnych i projektowych,

2) dokonywaniu podziałów oraz scalenia nieruchomości,

3) wyposażaniu (w miarę możliwości) w niezbędne urządzenia infrastruktury technicznej.

Na gruncie nauk ekonomicznych gospodarowanie oznacza proces dokonywania wyboru (podejmowania decyzji), zdeterminowany z jednej strony nieograniczonymi potrzebami człowieka, z drugiej zaś ograniczonymi możliwościami (zasobami ekonomicznymi) (Taylor, 1957; Wilczyński, 1965; Czaja, Becla, 2007; Czarny, 2011; Krugman, Wells, 2013; Kudłacz, 2013), według kryterium optymalizacji korzyści, jakie wiążą się z tymi decyzjami.

Potrzeby ludzkie są motywem wszelkiej aktywności człowieka, zarówno gospodarczej, jak i społecznej. Rodzaj i skala (wzrost) potrzeb jest adekwatny 
do osiągniętego poziomu rozwoju społeczno-gospodarczego i cywilizacyjnego. Wraz z osiągnięciem wyższego poziomu rozwoju gospodarczego, społecznego i kulturalnego pojawiają się nowe, dotychczas nierozpoznane potrzeby, którym towarzyszą nowe, większe możliwości ich zaspokojenia, aczkolwiek zawsze te możliwości są ograniczone (Wiszniewski, 1977; Szczepański, 1981).

Ograniczoność (rzadkość) zasobów jest odzwierciedleniem dysproporcji między zgłaszanym zapotrzebowaniem ludzi na dobra i usługi a ich dostępną ilością (Becla, Czaja, Zielińska, 2012). Ograniczoność zasobów (pracy, kapitału, ziemi) determinuje konieczność dokonywania wyborów między różnymi możliwościami zastosowania zasobów w celu zaspokojenia konkurujących ze sobą potrzeb. Wybory te, niezależnie od szczebla podmiotu podejmującego decyzję, dotyczą w szczególności:

1) tego, jakie dobra i usługi wytwarzać i w jakich ilościach,

2) tego, jak wytwarzać (jakimi metodami) i jakie angażować zasoby,

3) tego, kto będzie odbiorcą (dla kogo będą wytwarzane) dobra i usługi (Sloman, 2001),

4) hierarchii zaspokajanych potrzeb i ich kolejności w czasie.

Oznacza to, że w procesie gospodarowania wybór dokonywany jest między:

1) różnymi, nieograniczonymi celami różnych podmiotów,

2) przy ograniczonych zasobach, znajdujących wielość zastosowań,

3) z uwzględnieniem różnej hierarchii i ważności celów dla konkretnego podmiotu w czasie.

Gospodarowanie jest zatem celowym działaniem podmiotów (prywatnych, publicznych) dotyczącym rozdziału (zaangażowania) ograniczonych zasobów ekonomicznych między różne konkurencyjne zastosowania, z uwzględnieniem racjonalnych podstaw w gospodarowaniu ( $\mathrm{tj}$. działań zgodnych $\mathrm{z}$ celami na podstawie świadomego procesu kalkulacji efektów i nakładów).

Gospodarowanie nieruchomościami można zatem rozumieć jako proces podejmowania działań w sferze realnej i prawnej przez podmioty (publiczne i prywatne) w odniesieniu do nieruchomości, nakierowany na wybór, z punktu widzenia przyjętego celu, najkorzystniejszego rozwiązania spośród rozpatrywanych wariantów. Ta definicja gospodarowania nieruchomościami zawiera nie tylko prawne aspekty, ale uwzględnia ekonomiczny wymiar procesu gospodarowania (Trojanek, 2015).

\section{Cele gospodarowania nieruchomościami w gminach}

Głównym celem gospodarowania nieruchomościami stanowiącymi mienie gminy jest efektywne ich wykorzystanie w procesie wykonywania zadań publicznych przez gminę, to znaczy zaspokajanie zbiorowych potrzeb wspólnoty przez dostar- 
czanie lokalnych dóbr publicznych. Cele szczegółowe gospodarowania nieruchomościami są zróżnicowane w odniesieniu do funkcji przez te nieruchomości pełnionych. Nieruchomości komunalne mogą bowiem służyć do:

1) realizacji ustawowych zadań gminy (będą to funkcje o charakterze administracyjnym i użyteczności publicznej),

2) generowania strumieni dochodów jednorazowych (sprzedaż) bądź okresowych (np. czynsze dzierżawy, najmu),

3) realizacji przedsięwzięć inwestycyjnych bądź tworzenia rezerwy na realizację celów rozwojowych w przyszłości.

Drugim z obszarów gospodarowania nieruchomościami w gminie są działania dotyczące nieruchomości zlokalizowanych na jej terenie, a stanowiących mienie innych podmiotów. Oddziaływanie gminy w tym obszarze aktywności ma charakter pośredni, w odróżnieniu od gospodarowania nieruchomościami stanowiącymi mienie gminy. Gmina występuje wówczas w roli lokalnego gospodarza terenu, podmiotu polityki przestrzennej i polityki lokalnego rozwoju, a gospodarowanie nieruchomościami stanowi jeden z elementów zintegrowanej i spójnej polityki rozwojowej.

Celem gospodarowania nakierowanego na ten zasób nieruchomości jest kształtowanie i rozwój lokalnej przestrzeni zgodnie z celami rozwojowymi układu, określonymi w strategii rozwoju gminy oraz studium uwarunkowań i kierunków zagospodarowania przestrzennego gminy, tak by zapewnić optymalne funkcjonowanie lokalnego układu społeczno-gospodarczego, zgodnie z zasadami zrównoważonego rozwoju.

Syntetyczne ujęcie cech opisujących podobieństwa i różnice gospodarowania nieruchomościami publicznymi i prywatnymi przedstawiono w tabeli 1.

Tabela 1. Istota gospodarowania nieruchomościami publicznymi i prywatnymi - podobieństwa i różnice

\begin{tabular}{|l|l|l|}
\hline \multicolumn{1}{|c|}{$\begin{array}{c}\text { Kryteria } \\
\text { porównawcze }\end{array}$} & \multicolumn{1}{|c|}{ Publiczne } & \multicolumn{1}{c|}{ Prywatne } \\
\hline $\begin{array}{l}\text { Przedmiot } \\
\text { gospodarowania }\end{array}$ & $\begin{array}{l}\text { - Nieruchomości publiczne } \\
- \text { Nieruchomości prywatne - pośrednio }\end{array}$ & Nieruchomości prywatne \\
\hline $\begin{array}{l}\text { Ramy } \\
\text { gospodarowania } \\
\text { (przepisy prawa } \\
\text { i procedury) }\end{array}$ & $\begin{array}{l}\text { Przepisy prawa: } \\
\text { - powszechnie obowiązujące } \\
\text { - szczególne, uwzględniające } \\
\text { przeznaczenie nieruchomości } \\
\text {-zróżnicowane uregulowania }\end{array}$ & $\begin{array}{l}\text { Przepisy prawa o charakterze } \\
\text { powszechnym (uniwersalnym) } \\
\text { - Kodeks cywilny, Prawo bu- } \\
\text { dowlane, ustawa o gospodar- } \\
\text { ce nieruchomościami, ustawa } \\
\text { o planowaniu i zagospodaro- } \\
\text { waniu przestrzennym }\end{array}$ \\
\hline
\end{tabular}




\begin{tabular}{|l|l|l|}
\hline \multicolumn{1}{|c|}{$\begin{array}{c}\text { Kryteria } \\
\text { porównawcze }\end{array}$} & \multicolumn{1}{|c|}{ Publiczne } & \multicolumn{1}{c|}{ Prywatne } \\
\hline $\begin{array}{l}\text { Cele } \\
\text { gospodarowania }\end{array}$ & $\begin{array}{l}\text { Zróżnicowane w odniesieniu do funkcji } \\
\text { pełnionych przez nieruchomości } \\
\text { w procesie realizacji ustawowych zadań }\end{array}$ & $\begin{array}{l}\text { Zróżnicowane w zależności } \\
\text { od szeroko rozumianych } \\
\text { potrzeb właściciela, } \\
\text { zarówno bieżących, jak } \\
\text { i inwestycyjnych, a często } \\
\text { aspiracji, potrzeby szacunku }\end{array}$ \\
\hline $\begin{array}{l}\text { Podstawowa } \\
\text { zasada } \\
\text { podejmowania } \\
\text { decyzji }\end{array}$ & $\begin{array}{l}\text { Osiągnięcie zakładanego celu (efektu } \\
\text { użytkowego) przy minimalnym } \\
\text { zaangażowaniu zasobów - zasada } \\
\text { efektywnego wykorzystania zasobów }\end{array}$ & $\begin{array}{l}\text { Dążenie do uzyskania } \\
\text { maksymalnego efektu przy } \\
\text { danych nakładach }\end{array}$ \\
\hline $\begin{array}{l}\text { Struktura } \\
\text { rodzajowa } \\
\text { nieruchomości }\end{array}$ & $\begin{array}{l}\text { Zróżnicowanie ze względu na funkcje } \\
\text { pełnione przez nieruchomości i skalę } \\
\text { (wielkość zasobu) }\end{array}$ & $\begin{array}{l}\text { Najczęściej jednorodne } \\
\text { przeznaczenie, a także } \\
\text { mniejszy zasób }\end{array}$ \\
\hline $\begin{array}{l}\text { Główny cel } \\
\text { gospodarowania }\end{array}$ & $\begin{array}{l}\text { Stworzenie podstaw do realizacji } \\
\text { ustawowych zadań (zadania o charakterze } \\
\text { użyteczności publicznej) }\end{array}$ & $\begin{array}{l}\text { Zaspokajanie potrzeb } \\
\text { właściciela }\end{array}$ \\
\hline $\begin{array}{l}\text { Podmiot } \\
\text { gospodarujący }\end{array}$ & $\begin{array}{l}\text { Właścicielem nieruchomości jest podmiot } \\
\text { publiczny, a w jego imieniu i na rzecz } \\
\text { społeczeństwa gospodaruje właściwy organ }\end{array}$ & Właściciel nieruchomości \\
\hline
\end{tabular}

Źródło: Trojanek, 2015

Konieczność gospodarowania nieruchomościami dotyczy wszystkich rodzajów nieruchomości, niezależnie od tego, czy właścicielem jest podmiot publiczny, czy prywatny. Gospodarowanie nieruchomościami publicznymi powinno być skuteczne (działania podejmowane w gospodarce nieruchomościami powinny przyczyniać się do realizacji priorytetów i osiągania celów podmiotów gospodarowania) oraz efektywne (w przypadku pomiotów prywatnych powinny zapewniać jak najkorzystniejszą relację zakładanych efektów do poniesionych nakładów, a w przypadku podmiotów publicznych wykonanie określonych zadań przy minimalizacji zaangażowania nakładów).

\section{Działania podejmowane w procesie gospodarowania nieruchomościami}

Z teorii i doświadczeń gospodarowania nieruchomościami (zarówno w odniesieniu do krajów, w których rynek nieruchomości jest oceniany jako rozwinięty, jak również do krajów, w których rynek nieruchomości jest postrzegany jako rozwijający się) w świetle literatury przedmiotu i przeprowadzonych badań wynika, iż gospodarowanie nieruchomościami komunalnymi miało do końca lat osiemdziesiątych charakter reaktywny, to znaczy podejmowane decyzje były reakcją na potrzeby użytkowników. Gminy koncentrowały swoje działania na technicznych i opera- 
cyjnych aspektach nieruchomości, a nie na ich strategicznym wymiarze (Phelps, 2011). Wśród najczęstszych przyczyn tego stanu wymienia się (Kaganova, Nayyar-Stone, 2000; Grover, 2008; Deloitte EMEA, 2011):

1) duże zróżnicowanie portfela (zasobu) nieruchomości;

2) dużą fragmentaryzację zarządzania nieruchomościami;

3) brak planów strategicznych gospodarowania nieruchomościami na poziomie gmin (miast);

4) rozproszoną odpowiedzialność za zarządzanie nieruchomościami; nieruchomości stanowiły przedmiot zainteresowania różnych wydziałów, odpowiedzialnych za określony obszar działań;

5) brak spójności i komunikacji między wydziałami podejmującymi decyzje dotyczące nieruchomości;

6) nieefektywne gospodarowanie nieruchomościami, które dotyczyło nie tylko biednych krajów (Kaganova, McKellar, 2006; Zimmerman, 2008)

Podobne problemy związane z gospodarowaniem i zarządzaniem nieruchomościami komunalnymi występują także w polskich gminach (Informacja..., 2003; Informacja..., 2004; Brol, 2004; Brzeski, 2005; Proniewicz, Szczepańska, 2005; Sochacka-Krysiak, 2006; Informacja..., 2007; Informacja..., 2009; Karbownik, Kula, 2009; Brol, 2010; Informacja..., 2011; Nalepka, 2012; Wojciechowski, 2012a; 2012b; MSAP, 2013).

Jest oczywiste, iż nie ma jednego, uniwersalnego modelu gospodarowania (Łyszkiewicz, 2016; Wojciechowski, 1997). Jest on zdeterminowany wieloma okolicznościami, wśród których można wyróżnić (Vermiglio, 2011):
1) uwarunkowania polityczne,
2) uwarunkowania kulturowe,
3) uwarunkowania lokalne,
4) umiejętności kierownicze.

Powyższe okoliczności sprawiają, iż zmiany w gospodarowaniu nieruchomościami komunalnymi w poszczególnych krajach przebiegają $\mathrm{w}$ różnym tempie i zakresie. Tym niemniej są one wprowadzane (wymuszane) w warunkach (Phelps, 2011):

1) konieczności podnoszenia jakości usług świadczonych przez gminy,

2) socjoekonomicznych zmian,

3) ograniczonych zasobów finansowych.

Katalizatorem zmian w gospodarowaniu nieruchomościami nie były oczekiwania użytkowników, a ograniczenia budżetowe.

Zmiany w gospodarowaniu nieruchomościami publicznymi wynikają, jak pisze Phelps (2011), z odejścia od założeń państwa dobrobytu na rzecz kultury przedsiębiorczości opartej na wydajności i efektywności. Uwzględniając źródło zmian, można wyróżnić odgórne przekształcenia (np. Wielka Brytania, Nowa Zelandia, Australia, ale i kraje Europy Wschodniej) bądź z „dołu w górę” (np. USA). 
Przedstawione okoliczności determinują praktyczne rozwiązania w zakresie gospodarowania nieruchomościami w poszczególnych krajach. Niezależnie od okoliczności różniących można wskazać na pewne ogólne uwarunkowania o charakterze uniwersalnym, determinujące wzrost efektywności gospodarowania, a w szczególności:

1) prowadzenie ewidencji (rejestru) nieruchomości publicznych,

2) klasyfikację nieruchomości z punktu widzenia funkcji pełnionych przez nie w procesie realizacji zadań gminy,

3) szczegółowy opis nieruchomości, w tym określenie wartości księgowej i rynkowej nieruchomości,

4) opracowanie kryteriów pomiaru efektywności gospodarowania w odniesieniu do poszczególnych rodzajów nieruchomości,

5) pomiar kosztów i monitorowanie wyników poszczególnych rodzajów nieruchomości,

6) ustalenie standardów w zakresie ponoszonych kosztów i uzyskanych wyników,

7) stosowanie porównań z najlepszymi (tzw. benchmarki) - przedmiotem tych porównań mogą być podobne nieruchomości z sektora publicznego czy nieruchomości będące w zasobie podmiotu.

Zarówno w sektorze prywatnym (wcześniej), jak i w sektorze publicznym nastąpiło przewartościowanie w podejściu do aktywów, jakim są nieruchomości. Nieruchomości są postrzegane coraz częściej jako zasoby strategiczne niezbędne do osiągnięcia celów organizacji.

Nieruchomości komunalne stanowią podstawę materialną realizacji ustawowych zadań gminy (ujęcie tradycyjne), ale coraz częściej są postrzegane jako instrument stymulowania rozwoju lokalnego (oddziaływania na decyzje inwestycyjne podmiotów prywatnych) i możliwość pozyskiwania środków finansowych z rynku kapitałowego.

Strategia gospodarowania nieruchomościami powinna być zbieżna (spójna) $z$ celami strategicznymi samorządu terytorialnego, zapisanymi we wspomnianych dokumentach strategicznych oraz dokumentach o charakterze operacyjnym (np. miejscowych planach zagospodarowania przestrzennego). Cele gospodarowania, kryteria podejmowania decyzji, rola nieruchomości w procesie realizacji zadań gminy są zróżnicowane. Stąd podstawą procesu gospodarowania zasobem nieruchomości komunalnych powinna być klasyfikacja nieruchomości ze względu na realizację zadań (obecnie i w przyszłości) i potrzeby wynikające z dokumentów strategicznych. Uwzględniając to kryterium, najbardziej skuteczny wydaje się być podział nieruchomości na:

1) nieruchomości statutowe,

2) nieruchomości dochodowe,

3) nieruchomości instrumentalne. 
Tabela 2. Podział nieruchomości komunalnych z uwzględnieniem funkcji i kryteriów gospodarowania tymi zasobami

\begin{tabular}{|c|c|c|}
\hline $\begin{array}{c}\text { Grupy } \\
\text { nieruchomości }\end{array}$ & Rodzaje nieruchomości & $\begin{array}{l}\text { Funkcje nieruchomości. } \\
\text { Kryterium podejmowania } \\
\text { działań }\end{array}$ \\
\hline $\begin{array}{l}\text { Nieruchomości } \\
\text { statutowe } \\
\text { (funkcjonalne) }\end{array}$ & $\begin{array}{l}\text { - Obiekty administracji } \\
\text { - Budynki komunalne } \\
\text { - Grunty w użytkowaniu wieczystym } \\
\text { przeznaczone na cele mieszkaniowe } \\
\text { - Obiekty służące edukacji (przedszkola, } \\
\text { szkoły biblioteki) } \\
\text { - Obiekty służące ochronie zdrowia i pomo- } \\
\text { cy społecznej (zakłady opieki społecznej, } \\
\text { domy pomocy społecznej i domy dziecka) } \\
\text { - Obiekty i nieruchomości zajęte pod } \\
\text { urządzenia infrastruktury sieciowej (drogi, } \\
\text { wodociąg, gaz, kanalizacja) } \\
\text { - Obiekty kultury, zabytki } \\
\text { - Parki i tereny zieleni } \\
\text { - Wysypiska śmieci, oczyszczalnie ścieków } \\
\text { - Gminne targowiska } \\
\text { - Inne (np. cmentarze) }\end{array}$ & $\begin{array}{l}\text { Funkcje: stanowią materialną } \\
\text { bazę realizacji zadań z zakre- } \\
\text { su użyteczności publicznej. } \\
\text { Kryterium działania: racjo- } \\
\text { nalizacja kosztów realizacji } \\
\text { zadań. }\end{array}$ \\
\hline $\begin{array}{l}\text { Nieruchomości } \\
\text { instrumentalne: } \\
\text { - Społeczno- } \\
\text {-gospodarcze }\end{array}$ & $\begin{array}{l}\text { - Nieruchomości, które mogą wspierać } \\
\text { przedsiębiorczość w gminie (inkubator) } \\
\text { lub być udostępniane (wynajmowane, } \\
\text { wydzierżawiane na preferencyjnych } \\
\text { warunkach) }\end{array}$ & $\begin{array}{l}\text { Cel: wspieranie działań roz- } \\
\text { wojowych i tworzących za- } \\
\text { sób pod dalszy rozwój gminy; } \\
\text { są to nieruchomości czasowo } \\
\text { wykorzystywane na okre- } \\
\text { ślony cel } \\
\text { Kryterium działania: prefe- } \\
\text { rencyjne warunki udostępnia- } \\
\text { nia innym podmiotom }\end{array}$ \\
\hline - Rozwojowe & $\begin{array}{l}\text { - Nieruchomości stanowiące rezerwę pod } \\
\text { realizację inwestycji celu publicznego } \\
\text { - Nieruchomości znajdujące się na obszarze, } \\
\text { na którym nie ma aktualnego planu } \\
\text { zagospodarowania }\end{array}$ & $\begin{array}{l}\text { Zabezpieczają możliwość } \\
\text { realizacji zadań gminy } \\
\text { w przyszłości } \\
\text { Kryterium: czasowe udostęp- } \\
\text { nianie nieruchomości - np. } \\
\text { dzierżawa, najem } \\
\text { Dążenie do maksymalizacji } \\
\text { okresowych wpływów }\end{array}$ \\
\hline $\begin{array}{l}\text { Nieruchomości } \\
\text { dochodowe: } \\
\text { - Generujące } \\
\text { stałe } \\
\text { strumienie } \\
\text { dochodów }\end{array}$ & $\begin{array}{l}\text { - Lokale usługowe i lokale mieszkalne } \\
\text { wynajmowane na zasadach rynkowych } \\
\text { - Grunty oddane w użytkowanie wieczyste } \\
\text { i nieruchomości oddane w trwały zarząd } \\
\text { lub dzierżawę }\end{array}$ & $\begin{array}{l}\text { Funkcje: zasilają budżet } \\
\text { gminy, stanowią stałe źródło } \\
\text { dochodów } \\
\text { Kryterium działania: gmina } \\
\text { powinna podejmować działa- } \\
\text { nia zmierzające do optyma- } \\
\text { lizacji korzyści z tych nieru- } \\
\text { chomości }\end{array}$ \\
\hline
\end{tabular}




\begin{tabular}{|c|l|l|}
\hline $\begin{array}{c}\text { Grupy } \\
\text { nieruchomości }\end{array}$ & \multicolumn{1}{|c|}{ Rodzaje nieruchomości } & $\begin{array}{c}\text { Funkcje nieruchomości. } \\
\text { Kryterium podejmowania } \\
\text { dzialań }\end{array}$ \\
\hline $\begin{array}{c}\text { - Generujące } \\
\text { jednorazowy } \\
\text { dochód }\end{array}$ & $\begin{array}{c}\text { - Lokale mieszkalne przeznaczone } \\
\text { do sprzedaży na rzecz najemców } \\
- \text { Grunty niezabudowane o różnych } \\
\text { funkcjach } \\
- \text { Grunty zabudowane różnymi obiektami }\end{array}$ & $\begin{array}{l}\text { Funkcje nieruchomości: nie- } \\
\text { ruchomości, które są zbęd- } \\
\text { ne (nie należą do funkcjonal- } \\
\text { nych ani instrumentalnych) } \\
\text { z punktu widzenia zadań } \\
\text { bieżących i rozwojowych } \\
\text { Kryterium podejmowania } \\
\text { działań: działania prowadzą- } \\
\text { ce do maksymalizacji wpły- } \\
\text { wów przez wzrost wartości } \\
\text { i zmniejszenie kosztów utra- } \\
\text { conych korzyści }\end{array}$ \\
\hline
\end{tabular}

Źródło: Trojanek, 2015

W odniesieniu do wyróżnionych grup (kategorii) możliwe są różne warianty, sposoby, metody i formy ich wykorzystania. Władze samorządowe powinny ustalić (zróżnicowane w odniesieniu do wyróżnionych grup, z uwzględnieniem przyjętych priorytetów lokalnej strategii rozwoju) zasady nabywania i zbywania nieruchomości komunalnych.

Zakwalifikowanie nieruchomości do określonej kategorii powinno być dokonane z punktu widzenia ich przydatności w procesie realizacji zadań gminy (ustawowych i innych), w ujęciu dynamicznym. Oznacza to konieczność monitorowania przydatności i podejmowania decyzji o przeznaczeniu nieruchomości, stosownie do zachodzących zmian w mechanizmach kształtowania rozwoju.

Klasyfikacja nieruchomości wymaga znajomości wielkości i struktury zasobu. Stąd potrzeba przeprowadzenia inwentaryzacji stanu posiadania i bieżącej ewidencji zmian. W ramach tych czynności zachodzi potrzeba opisu stanu nieruchomości, zintegrowania różnorodnych danych (ewidencyjnych, prawnych, technicznych i ekonomiczno-finansowych), nie tylko w celach księgowych, ale także do wykorzystania w procesach gospodarowania tymi aktywami.

W procesie gospodarowania istotna jest znajomość (poza wielkością i strukturą zasobu) nie tylko księgowej, ale przede wszystkim rynkowej wartości nieruchomości. Stąd, z punktu widzenia oceny efektywności podejmowanych działań, ważne jest gromadzenie danych rynkowych i informacji o zmianach na lokalnym rynku nieruchomości. Analiza powinna dotyczyć tych segmentów rynku nieruchomości, które generują lub mogą generować dochód w przyszłości (grunty przeznaczone na cele komercyjne, grunty pod budownictwo mieszkaniowe, zasoby lokalowe, obiekty na wynajem), zwłaszcza cen uzyskanych za podobne nieruchomości, stawek dzierżawy czy stawek najmu.

W okresowej ocenie wyników gospodarowania nieruchomościami powinny być uwzględnione, poza dochodami generowanymi przez nieruchomości, rów- 
nież wydatki operacyjne związane z utrzymaniem i eksploatacją nieruchomości, a także koszty niezbędnych remontów i modernizacji. Dla nieruchomości funkcjonalnych obniżka kosztów eksploatacji, przy stałym zakresie i poziomie jakości świadczonych usług, świadczy o poprawie tego wskaźnika, natomiast przy nieruchomościach dochodowych istotny jest wzrost osiąganych dochodów (np. z dzierżaw czy najmu).

Kolejnym etapem w procesie gospodarowania nieruchomościami komunalnymi jest ocena potrzeb wynikająca z dokumentów o charakterze strategicznym. Powinna być ona podstawą do podjęcia stosownych decyzji dotyczących:

1) nabywania nieruchomości do zasobu gminnego,

2) czasowego udostępniania nieruchomości innym podmiotom,

3) sprzedaży zbędnych nieruchomości,

4) podejmowania działań rozwojowych dotyczących nieruchomości zabudowanych (np. rozbudowa, modernizacja, remont itp.).

\begin{tabular}{|c|}
\hline Wdrażanie strategii: \\
- określenie podmiotu odpowiedzialnego za realizację strategii \\
- określenie instrumentów \\
- monitorowanie skuteczności i efektywności \\
\hline
\end{tabular}

$\uparrow$

\begin{tabular}{|l|}
\hline Przyjęcie strategii gospodarowania nieruchomościami: \\
- opracowanie szczegółowych programów i zadań w odniesieniu do grup nieruchomości \\
pełniących zróżnicowane funkcje w realizacji zadań gminy \\
- określenie możliwości finansowych gminy \\
- określenie form i zasad dysponowania \\
\hline
\end{tabular}

\begin{tabular}{|c|c|c|}
\hline \multicolumn{3}{|c|}{ Określenie celów gospodarowania nieruchomościami } \\
\hline$\uparrow$ & $\uparrow$ & $\uparrow$ \\
\hline Klasyfikacja nieruchomości & & \\
\hline $\begin{array}{c}\uparrow \\
\begin{array}{c}\text { Inwentaryzacja i ewidencja } \\
\text { nieruchomości }\end{array}\end{array}$ & $\begin{array}{c}\text { Analiza lokalnego rynku } \\
\text { nieruchomości }\end{array}$ & $\begin{array}{c}\text { Ocena potrzeb z punktu } \\
\text { widzenia realizacji zadań } \\
\text { gminy }\end{array}$ \\
\hline
\end{tabular}

Rysunek 1. Etapy opracowania i wdrażania strategii (programu) gospodarowania nieruchomościami w gminie

Źródło: opracowanie na podstawie Wartalska, 2004; Dziworska, Trojanowski, 2008; Filipiak, 2011.

Modelowy proces opracowania strategii gospodarowania nieruchomościami komunalnymi obejmuje zatem czynności, które można ująć w etapy, a w nich wyróżnić pewne działania.

Działania te prowadzą do rozpoznania i oceny stanu istniejącego w zakresie gospodarowania nieruchomościami. Są podstawą do sformułowania celów gospo- 
darowania, opracowania szczegółowych programów i zadań dotyczących grup nieruchomości, wynikających z przyjętych dokumentów strategicznych, wraz z określeniem możliwości finansowych i harmonogramu realizacji (cele, priorytety, programy). Kolejny etap działań obejmuje wybór form i zasad gospodarowania nieruchomościami.

Uwzględniając dorobek literatury przedmiotu i własne przemyślenia w omawianych kwestiach, przedstawiono propozycję działań w procesie opracowania i wdrażania strategii gospodarowania nieruchomościami w gminie (rysunek 1).

Efekty gospodarowania nieruchomościami w poszczególnych gminach są/ będą zróżnicowane, jeśli chodzi o rodzaj, zakres i skalę, w zależności od przyjętych celów w dokumentach strategicznych czy programach sektorowych, od prowadzonej lokalnej polityki gospodarowania nieruchomościami (aktywna bądź pasywna) czy stosowanych instrumentów (planistyczne bądź realizacyjne).

\section{Podsumowanie}

Ze względu na zakres artykułu rozważania koncentrują się na wybranych aspektach gospodarowania nieruchomościami komunalnymi. Mając na uwadze prawne i ekonomiczne uwarunkowania gospodarowania nieruchomościami komunalnymi oraz cele gospodarowania zasobem i funkcje przez ten zasób pełnione w procesie wykonywania zadań gminy, wskazano na zasadność strategicznego podejścia do gospodarowania nieruchomościami.

Z teorii i praktyki gospodarowania nieruchomościami wynika, iż nie ma uniwersalnego modelu gospodarowania. Przesłanki zmian dokonujących się w podejściu do gospodarowania nieruchomościami wynikają w szczególności z potrzeb racjonalizacji kosztów utrzymania tego zasobu, dokonujących się zmian w wielkości i strukturze zasobu czy potrzeby zwiększenia efektywności gospodarowania tym zasobem. Nieruchomości komunalne stanowią bowiem nie tylko podstawę materialną realizacji ustawowych zadań gminy, ale są/mogą być instrumentem stymulowania rozwoju lokalnego i umożliwiać pozyskiwanie środków z rynku kapitałowego. Stąd za konieczne uznać należy nadanie gospodarowaniu nieruchomościami komunalnymi wymiaru strategicznego. 


\section{Bibliografia}

Becla A., Czaja S., Zielińska A. (2012), Analiza kosztów - korzyści w wycenie środowiska przyrodniczego, Wydawnictwo Difin, Warszawa.

Brol R. (2004), Ekonomika i zarządzanie miastem, Wydawnictwo Akademii Ekonomicznej we Wrocławiu, Wrocław.

Brol R. (2010), Zarys ekonomii sektora publicznego, Wydawnictwo Uniwersytetu Ekonomicznego we Wrocławiu, Wrocław.

Brzeski P. (2005), Zarzadzanie mieniem komunalnym w miastach polskich, [w:] J. Proniewicz, K. Szczepańska (red.), Efektywna polityka i administracja. Strategie i instrumenty zarzadzania miastami, Związek Miast Polskich, Poznań.

Czaja S., Becla A. (2007), Ekologiczne podstawy procesów gospodarowania, Wydawnictwo Akademii Ekonomicznej we Wrocławiu, Wrocław.

Czarny B. (2011), Podstawy ekonomii, Polskie Wydawnictwo Ekonomiczne, Warszawa.

Deloitte EMEA (2011), Municipal real estate. Comparing public estate management in European cities, www.deloitte.com [dostęp: 1.04.2017].

Dziworska K., Trojanowski D. (2008), Podstawy strategii zarządzania nieruchomościami komunalnymi, [w:] W. Golnau (red.), Inwestycje i nieruchomości. Wybrane problemy, Fundacja Uniwersytetu Gdańskiego, Sopot.

Filipiak B. (2011), Finanse samorządowe. Nowe wyzwania bieżace i perspektywistyczne, Difin, Warszawa.

Grover R. (2008), State and Public Land Management: The Drivers of Change, https://www.fig. net/resources/proceedings/2008/verona_fao_2008_comm7/papers/09_sept/2_3_grover.pdf [dostęp: 1.04.2017].

Informacja o wynikach kontroli dysponowania mieniem komunalnym przez gminy województwa kujawsko-pomorskiego (2011), NIK, Warszawa.

Informacja o wynikach kontroli gospodarowania gminnymi lokalami użytkowymi i efektywności zarzadzania tymi lokalami (2004), NIK, Warszawa.

Informacja o wynikach kontroli zarządzania nieruchomościami gminnymi (2007), NIK, Warszawa.

Informacja o wynikach kontroli zbywania nieruchomości gminnych w latach 2005-2008 (2009), NIK, Warszawa.

Informacja o wynikach kontroli zbywania nieruchomości komunalnych przez gminy (2003), NIK, Warszawa.

Kaganova O., McKellar J. (2006), Managing Government Property Assets: International Experiences, The Urban Institute Press, Washington.

Kaganova O., Nayyar-Stone R. (2000), Municipal Real Property Asset Management. An Overview of World Experience, ,Journal of Real Estate, Portfolio Management”, t. G, nr 4, s. 307-326.

Karbownik B., Kula G. (2009), Efektywność sektora publicznego na poziomie samorządu lokalnego, „Materiały i Studia”, z. 212, Wydawnictwo NBP, Warszawa.

Krugman P., Wells R. (2013), Mikroekonomia, Wydawnictwo Naukowe PWN, Warszawa.

Kudłacz T. (2013), Finansowe aspekty polityki przestrzennej samorzadów terytorialnych, [w:] A. Nowakowska, (red.), Zrozumieć terytorium. Idea i praktyka, Wydawnictwo Uniwersytetu Łódzkiego, Łódź.

Łyszkiewicz M. (2016), Gospodarowanie majątkiem komunalnym. Zasady, metody, strategie, CeDeWu.pl, Warszawa.

MSAP (2013), Narastajace dysfunkcje, zasadnicze dylematy, konieczne działania. Raport o stanie samorzadności terytorialnej w Polsce, t. 2, Uniwersytet Ekonomiczny w Krakowie, Małopolska Szkoła Administracji Publicznej, Kraków. 
Nalepka A. (2012), Efekty gospodarowania gminnym zasobem nieruchomości i możliwości ich powiększania, [w:] T. Dudycz, G. Osbert-Pociecha, B. Barycz (red.), Efektywność - konceptualizacja i uwarunkowania, Wydawnictwo Uniwersytetu Ekonomicznego w Krakowie, Kraków.

Phelps A. (2011), Municipal Property Asset Management. A Comparative Study of UE and Russia, „International Journal of Strategic Property Management”, t. 15, nr 4, s. 157-174.

Proniewicz J., Szczepańska K. (red.) (2005), Efektywna polityka, administracja, strategie i instrumenty zarzadzania miastami, Związek Miast Polskich, Poznań.

Sloman J. (2001), Podstawy ekonometrii, Polskie Wydawnictwo Ekonomiczne, Warszawa.

Sochacka-Krysiak H. (2006), Zrządzanie gospodarka i finansami gminy, Wydawnictwo Szkoły Głównej Handlowej, Warszawa.

Szczepański J. (1981), Konsumpcja a rozwój człowieka. Wstęp do antropologicznej teorii konsumpcji, Państwowe Wydawnictwo Ekonomiczne, Warszawa.

Taylor E. (1957), Historia rozwoju ekonomiki, t. 1, Państwowe Wydawnictwo Naukowe, Warszawa.

Trojanek M. (2015), Gospodarowanie nieruchomościami w gminach w aspekcie ich dochodowości, Wydawnictwo Uniwersytetu Ekonomicznego w Poznaniu, Poznań.

Ustawa z dnia 21 sierpnia 1997 r. o gospodarce nieruchomościami (Dz.U. z 1997 r. Nr 115, poz. 741).

Vermiglio C. (2011), Public Property Management in Italian Municipalities, „Property Management", nr 29(5), s. 423-442.

Wartalska M. (2004), Wybrane przesłanki budowy programów zarządzania majątkiem komunalnym w aspekcie gospodarowania finansami miasta, [w:] Konkurencyjność i potencjat rozwoju polskich metropolii - szanse i bariery, „Biuletyn Komitetu Przestrzennego Zagospodarowania Kraju PAN", z. 214, Warszawa.

Wilczyński W. (1965), Rachunek ekonomiczny a mechanizm rynkowy, Państwowe Wydawnictwo Ekonomiczne, Warszawa.

Wiszniewski E. (1977), Ekonomika konsumpcji, Państwowe Wydawnictwo Naukowe, Warszawa.

Wojciechowski E. (1997), Samorzad terytorialny w warunkach gospodarki rynkowej, Wydawnictwo Naukowe PWN, Warszawa.

Wojciechowski E. (2012a), Gospodarka samorzadu terytorialnego, Difin, Warszawa.

Wojciechowski E. (2012b), Zarzadzanie w samorzadzie terytorialnym, Difin, Warszawa.

Zimmerman W. (2008), Effective and Transparent Management of Public Land Experiences, Guilding Principles and Tools for Implementation, https://fig.net/resources/monthly_articles/2008/ december_2008/december_2008_zimmermann.pdf [dostęp: 1.04.2017].

\title{
Strategic Dimension of Municipal Real Estate Stock Administration
}

\begin{abstract}
The aim of the paper was to prove the legitimacy of the strategic approach to administration of municipal real estates. The author introduced the legal and economic aspects of the municipal real estate stock administration, and she emphasized the specificity and goals set in the process of administrating the subject stock. In the course of the research, the arguments for reshaping the municipal real estate stock administration model were identified. The arguments were based on the assumption that the administration process should be derived from the classification of real estates according to (current and future) municipal tasks and needs stipulated in strategic documents. The study also comprised the description of activities taken up by local authorities in subsequent stages of designing the strategy of municipal real estate administration.
\end{abstract}

Keywords: real estate administration, aims of real estate administration, real estate administration strategy

JEL: $\mathrm{R} 5, \mathrm{H} 7, \mathrm{~K} 3$ 


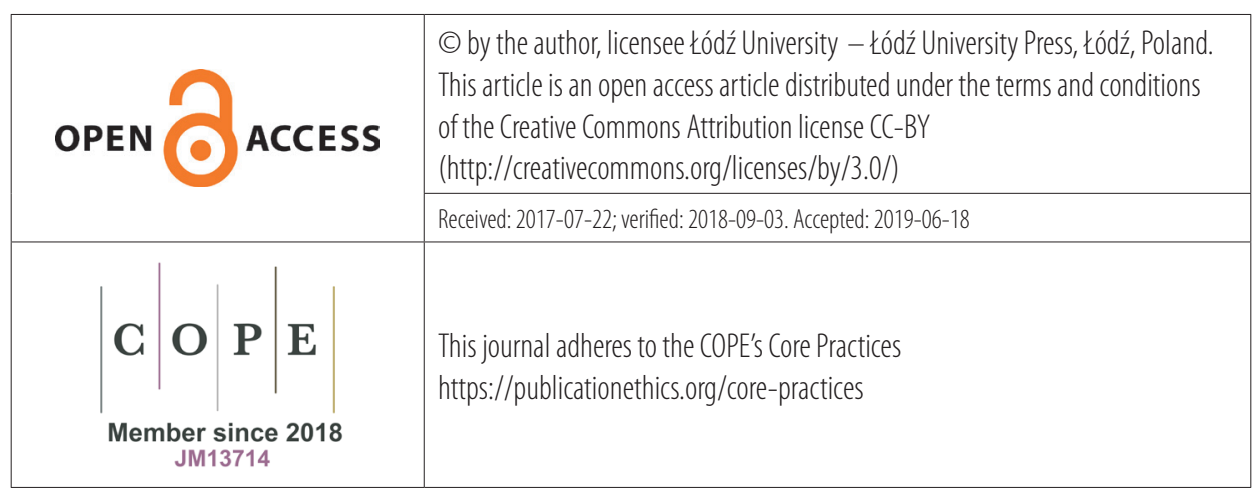


